\title{
Gebedsterapie in die verwerking van traumageheue
}

\author{
Authors: \\ Amanda L. du Plessis ${ }^{1}$ \\ Barend J. de Klerk ${ }^{1}$ \\ Affiliations: \\ ${ }^{1}$ Department of Practical \\ Theology, Potchefstroom \\ Campus, North-West \\ University, \\ South Africa \\ Correspondence to: \\ Amanda du Plessis

\section{Email:} \\ amanda.duplessis@nwu. \\ ac.za

\section{Postal address:} \\ Unit for Reformative \\ Theology, Faculty of \\ Theology, Internal Box 147, \\ North-West University, \\ Private Bag X6001, \\ Potchefstroom 2520, \\ South Africa \\ Dates: \\ Received: 18 Feb. 2011 \\ Accepted: 06 June 2011 \\ Published: 04 Dec. 2012 \\ How to cite this article: \\ Du Plessis, A.L. \& De Klerk \\ B.J., 2012, 'Gebedsterapie \\ in die verwerking van \\ traumageheue', In die \\ Skriflig/In Luce Verbi \\ 46(2)2012, Art. \#67, 8 pages \\ http://dx.doi.org/10.4102/ \\ ids.v46i2.67
}

C) 2012. The Authors. Licensee: AOSIS OpenJournals. This work is licensed under the Creative Commons Attribution License.
Die vraag wat in hierdie artikel ondersoek word, is of gebed enige rol speel in die herwinning en verwerking van traumageheue tydens die proses van innerlike genesing. Die emosioneel verwonde persoon word soms op verskeie vlakke van die lewe gekortwiek as gevolg van hierdie emosionele pyn. Vir innerlike genesing om te realiseer, is dit nodig dat die persoon die onderdrukte, onverwerkte emosies wat op 'n traumagebeurtenis volg, moet erken en verwerk. In baie gevalle is dit egter onmoontlik vir die persoon om die skakeling te maak tussen sy of haar huidige probleme en onderdrukte, onverwerkte emosies. In gevalle waar daar dissosiasie plaasgevind het, kan die persoon nie die emosies spontaan herroep en hanteer nie. Dit is onder andere in sulke gevalle waar gebedsterapie van groot waarde kan wees. Tydens gebedsterapie tree die pastorale berader as fasiliteerder op om die persoon na Jesus Christus te bring sodat Hy hom kan genees. In werklikheid word Jesus Christus se bediening steeds voortgesit. Oorwinning oor pynlike trauma-herinneringe stel die mens in staat om emosionele en geestelike groei te beleef.

Prayer therapy in the healing of traumatic memories. The research question in this article pertains to whether prayer has a place in recovering and healing traumatic memories during the process of inner healing. A person is often challenged at different levels because of emotional pain. For inner healing to happen, suppressed memories need to be identified and processed. In many cases the person finds it impossible to make a connection between current problems and repressed emotions. When dissociation occurs, the person cannot spontaneously recall these emotions. It is in such cases that prayer therapy may prove to be of value. During prayer ministry the counsellor acts as facilitator leading the counselee by faith into the presence of Jesus Christ for healing. On effect, the earthly ministry of Jesus Christ is continued in this way. Conquering painful, traumatic memories in this manner will help the person to grow spiritually and recover emotionally.

\section{Inleiding}

Vanuit die pastorale beradingsvertrekpunt kan gebed beskryf word as meer as net 'n beradingstegniek, omdat dit binne berading die primêre voertuig tot geestelike groei is. Ondanks die krag en belangrikheid van gebed, blyk dit dat die integrering van gebed in die innerlike genesingsproses geensins 'n eenvoudige taak is nie (McMinn 1996:91). Minder as 'n dekade gelede is gebed nog binne die hoofstroom van die hulpverleningsprosesse met 'n groot mate van suspisie bejeën as gevolg van 'n verskeidenheid van vrae ten opsigte van morele kwessies. Gebed is daarom as moeilik definieerbaar beskryf en hoofsaaklik geassosieer met Christelike fundamentalisme (Gubi 2001:425). Die huidige groeiende navorsing oor die gebruik van gebed in die beradings- en terapeutiese hulpverleningsproses is egter ' $n$ bewys dat gebed definitiewe terapeutiese waarde het en dat gebedsterapie 'n deurslaggewende rol speel met betrekking tot die persoon se genesing en lewenskwaliteit (vgl. Smith 1999, 2007; MacNutt 1999; Seamands 2001; Richardson 2005; Campbell-Lane \& Lotter 2005; Campbell-Lane 2003).

Ten spyte hiervan is dit belangrik om in ag te neem dat nie alle persone wat aanmeld vir terapie bedien kan word met gebedsterapie nie. Persone wat nie Christene is nie, mag onwillig wees om deur die gebed met God tot 'n verhouding met Jesus Christus gebring te word. Ook ateïste sal waarskynlik onwillig wees om gebedsterapie te ontvang. In die lig hiervan moet die pastorale berader sensitief ingestel wees om die regte beradingstegniek op verskillende persone toe te pas. Vir die doeleindes van hierdie artikel val die fokus egter op die pastorale berader wat die Christenpersoon vanuit ' $n$ Christelike basis begelei tot geestelike en emosionele genesing. Die vraag wat ondersoek word, is: Kan gebed enigsins deel uitmaak van die proses van die herwinning en verwerking van traumageheue in die innerlike genesingsproses? Traumageheue veronderstel onverwerkte, onderdrukte emosionele bagasie as gevolg van 'n traumatiese 
gebeurtenis in die beradene se lewe. Wanneer 'n persoon nie oor die emosionele kapasiteit beskik om 'n gebeurtenis te hanteer of te verwerk nie, vind dissosiasie plaas en 'vergeet' of onderdruk die brein die gebeurtenis. Aanvanklik is die dissosiasie 'n verdedigingsmeganisme, maar later vorm dit 'n struikelblok vir verdere geestelike en emosionele groei. Dit is in hierdie proses waar die pastorale berader die beradene moet help om die traumageheue te herwin en te verwerk, sodat geestelike en emosionele groei kan plaasvind.

Vir meer duidelikheid word die terme innerlike genesing, gebed en gebedsterapie omskryf:

- Innerlike genesing is die proses waartydens die emosioneel en geestelik verwonde persoon, van die Heilige Gees, dieper insig en begrip verkry in die pyn en wonde van sy of haar verlede, asook in die negatiewe effek wat dit op sy of haar funksioneringstyl het. Die doel is dat hy of sy genesing ontvang van die pynlike herinneringe en in staat is om die negatiewe denkpatrone te herprogrammeer (Seamands \& Funk 1992:22; Allender 1995:19; MacNutt 1999:146; Minirth 2003:36).

- Gebed kan gedefinieer word as die gemeenskap binne die raamwerk van die verbondsverhouding tussen God en die mens waartydens gesprekvoering plaasvind. Die Heilige Gees is deur die gebed werksaam in hierdie gesprek waarin die mens in vertroue en geloof na God roep (Berkhof 1973:513; Bounds 1984:39; Goldsworthy 2003:183).

- In gebedsterapie vorm gebed as 't ware die kanaal waardeur innerlike genesing kan plaasvind, wanneer die pastorale berader die beradene deur voortdurende gebed in die teenwoordigheid van God in Jesus Christus deur die werking van die Heilige Gees bring (Du Plessis 2007:180).

\section{Metodologie}

In navolging van die model van Zerfass (1974) maak hierdie artikel deel uit van die basisteorie, waar teologiese oorlewering deur middel van 'n literatuurstudie nagevors word. In hierdie verband gaan dit spesifiek oor die rol wat gebed tydens die innerlike genesingsproses in die herwinning en verwerking van traumageheue kan inneem. Verskillende Christenpsigiaters, -sielkundiges, -terapeute en ander pastorale outeurs en navorsers wat vanuit 'n Bybelse vertrekpunt ondersoek ingestel het na die rol van gebed in die innerlike genesingsproses, is nagevors (Anderson, Zeulke \& Zeulke 2000; Ferguson, Willemsen \& Castarieto 2010; Kuchan 2009; Smith 1999, 2007). Hierdie artikel se fokus is tweeledig: eerstens Jesus Christus se werksaamheid in die bediening van innerlike genesing; en tweedens die proses van gebedsterapie soos wat dit vandag tipies in die beradingspreekkamer voorkom. Die teologiese invalshoek vind plaas vanuit die reformatoriese teologie waar klem gelê word op die Drie-enige God, die Woord van God, die verbondsverhouding tussen God en die mens, en in hierdie geval ook op gebed as die gemeenskap met God binne die verbondsverhouding.

\section{Jesus Christus se werksaamheid in die bediening van innerlike genesing}

Gebedsterapie is die sinkronisering van psigiese en geestelike sisteme waardeur 'n Christenberader as fasiliteerder 'n beradene met trauma en emosionele probleme begelei tot in die teenwoordigheid van God, sodat Jesus Christus, wat alle mag in hemel en op aarde ontvang het, hierdie persoon op Goddelike wyse kan genees en bevry (Ferguson et al. 2010:310). Gebedsterapie en berading geskied daarom altyd onder die leiding van die Heilige Gees. Die beradene word op 'n unieke wyse in die volle waarheid (Joh 8:32) ingelei, sodat hy of sy in staat sal wees om sy of haar lewe verantwoordelik te bestuur, sy of haar potensiaal te ontwikkel en in oorwinning sy of haar skeppingdoel te verwesenlik (Jones 2007:25). Jesus Christus se genesende werksaamheid is altyd in verband met God se beloftes aangaande die lyding van die mens gebring (Lindeque 2006:118). Pastorale berading as terapie staan daarom in ' $n$ baie noue verband met die koninkryksdimensie wat ingelei is met die koms van Jesus Christus na hierdie wêreld (Thiessen 2009:142).

In die bybelse tyd het mense groot waarde aan die betekenis van iemand se naam geheg (MacNutt 1999:28). Die keuse van 'n naam was dikwels ook 'n aanduiding van die rol wat die betrokke persoon veronderstel was om in die samelewing te vertolk. Jesus (Yeshua in die oorspronklike Aramees) beteken die Here verlos. Vanuit die evangelies blyk dit dat Jesus Christus se werk as die Verlosser hoofsaaklik 'n drieledige fokus gehad het, naamlik lering, evangelisering en genesing (Du Plessis 2007:46). Hierdie fokus is vervat in die opdrag aan die dissipels (Luk 9:1-2, 11; Luk 10:1, 8-9), asook in die opdrag aan die kerk (Hand 4:29-31). Jesus Christus lê die grondslag vir die bediening van alle berading en genesing, want genesing het ' $n$ besondere deel uitgemaak van sy aardse bediening. Sy kruisdood en opstanding vorm die grond waarop gelowige beraders kan staan wanneer hulle biddend wetenskaplike beradingsmetodes aanwend. Christus se boodskap was een van verlossing deur diepgaande innerlike nuutwording as gevolg van die afsterwe van die ou natuur en die opstanding van die nuwe natuur deur die kragtige werking van God se Gees (Sandford \& Sandford 1982:06). Die gebed sal in hierdie vernuwingsproses wat in die mens plaasvind ' $n$ al meer betekenisvolle rol inneem. Gebed is daarom meer as net blote verbale kontak tussen God en die mens; in hierdie sin is gebed eerder 'n wederkerige aktiwiteit waarin die mens sy of haar afhanklikheid van Christus bely en God in Christus sy genade deur die kragtige verhoring van gebede betoon (Sinclair 1993:104).

Die Here Jesus se bediening fokus in 'n baie sterk mate op die innerlike lewe van die mens (Meier, Arterburn \& Minirth 1999:108; Friesen 1997:214). Dit blyk byvoorbeeld uit 'n gedeelte soos Matteus 11:28 waar die vermoeides en belastes geroep word om in 'n intieme verhouding met Hom te lewe: 'Kom na My toe ... en Ek sal julle rus gee.' 
MacNutt (1999:40) beskryf Jesus se bediening kortliks soos volg:

- eerstens skenk Jesus nuwe lewe aan die mens, sodat hy of sy deur die Heilige Gees in 'n liefdevolle verhouding van eenheid met sy of haar Hemelse Vader en Jesus Christus leef; en

- tweedens bied Christus verlossing en genesing in die mens se lewe, wat getransformeer moet word, sodat die mens nuut kan wees en die nuwe lewe kan uitstraal.

Hierdie verhouding impliseer 'n nuutwording betreffende alle dimensies in die mens se lewe (Gushee 2007:72). Die Heilige Gees begelei die mens in die proses van verandering waar die ou sondige natuur afgesterf word en die nuwe natuur in Christus opgeneem word (2 Kor 3:18 en 1 Kor 3:16). Alhoewel die mens wedergebore is en tot bekering gekom het, is sy of haar emosies, verstand en wil nog vasgevang in die stryd met die ou sondige natuur en moet daar voortdurende vernuwing plaasvind (Campbell-Lane 2003:181; Friesen 1997:217). Hierdie vernuwing en verandering beteken eerstens 'n erkenning dat die mens nie uit eie krag kan verander nie; tweedens 'n besef dat hy of sy hom of haar totaal aan God moet onderwerp; en derdens die oortuiging dat Jesus Christus hom of haar met volkome genesing kan bedien. In hierdie proses vorm gebed ' $n$ belangrike onderdeel. Wanneer 'n individu in gebreke bly om 'n toegewyde gebedslewe te lei, is hy of sy baie meer vatbaar vir byvoorbeeld uitbranding en die psigiese spanning wat daarmee gepaard gaan (Minirth, Hawkins \& Flournoy 1986:35). Die liggaam is dus geneig om die uiterlike reaksies van die mens se innerlike lewe te reflekteer.

Colbert (2003:6) verduidelik hierdie noue verband tussen liggaam en gees as 'n basiese vertrekpunt in die onderrig van Jesus Christus. Hy het in hierdie verband die mense gewaarsku dat hulle nie bevrees moet wees vir diegene wat die vermoë het om hulle liggame te vernietig nie, aangesien hulle gees buite die bereik van sulke optredes is (Matt 10:28). Daar is dus ' $n$ wêreld van nie-materiële realiteit. Christus het ook herhaaldelik aan mense wat liggaamlike genesing ervaar het, gesê: 'Jou geloof het jou gered.' Hieruit kan afgelei word dat die wêreld van nie-materiële realiteit 'n konkrete invloed het op die mens se fisiese bestaan (Mark 2:1-12; Poloma 2009:59; Stanley 2009:830). Die holistiese aard van die mens het tot gevolg dat die verskillende dimensies 'n onderlinge effek op mekaar het (Minirth \& Meier 1990:13). Sodoende kan 'n fisiese ongesteldheid byvoorbeeld aanleiding gee tot 'n psigiese afwyking en vice versa. Hierdie afwykings het gewoonlik ook 'n verdere negatiewe effek op die geestelike dimensie van die betrokke individu.

Dit is dus uit bogenoemde duidelik dat Jesus in sy bediening die klem ook op die innerlike van die mens se lewe gelê het.

\section{Die proses van gebedsterapie}

Verskillende fases en stappe kan onderskei word tydens gebedsterapie wat die ontwikkelingsgang van die beradingsproses aandui ${ }^{1}$ (Du Plessis 2007:62; Thiessen 2009:81). Die voorgestelde pastorale begeleidingsproses word vervolgens in drie hooffases verdeel ten einde sodoende die nodige uitkomste te bereik. In al drie fases speel gebed die deurslaggewende rol. Die drie fases is:

- die terapeutiese gesprek, waartydens die berader agtergrondkennis oor die beradene, die simptome en die moontlike oorsake inwin;

- die gespreksgebed, waartydens die beradene na Jesus Christus begelei word, sodat emosionele genesing en geestelike vernuwing kan plaasvind;

- die nasorg en begeleiding tot emosionele en geestelike groei.

Die verloop van die fases kan oorvleuel. Terapie kan in enige fase begin word, maar sorg moet gedra word dat elke fase ten volle deurgewerk word.

\section{Fase 1: Die terapeutiese gesprek}

Ohlschlager en Scalise (2007:19) beskryf hierdie fase as die identifisering van probleme en geleenthede. In Draper (1996:149-206) se model handel hierdie fase oor die ontdekking en erkenning van die probleem. Allender (1995:43) en Langberg (2003:215) beskryf dit as die besondere fokus op die omstandighede waarin die emosionele verwonding plaasgevind het, want die fokus van die terapeutiese gesprek is ook op die erkennning van die emosionele wonde gerig. Die fase bestaan uit drie stappe wat interaktief is, met ' $n$ wisselwerking tussen die onderskeie stappe.

\section{Stap 1 (Fase 1): Berei die beradene voor}

Alhoewel geen riglyne as absolute vereistes vir 'n beradingsessie uitgespel kan word nie, beklemtoon Wright (1985:53) en Kraft (1993:96) tog die belangrikheid om by die aanvang van elke sessie te bid vir die leiding van die Heilige Gees; vir die krag van die Heilige Gees sodat emosionele genesing kan realiseer; die regte gedagtes, woorde en leiding; en die beskerming teen en geestelike onderskeiding ten opsigte van gedagtes en invloede van Satan. Die grootste verskil tussen gebedsterapie en berading in die algemeen is dat die beradene tydens gebedsterapie aangespoor word om nie slegs logies of kognitief ingestel te wees nie, maar om sy of haar emosies te erken en dit nie langer te probeer onderdruk nie, om sodoende die intensiteit van die pyn as 't ware te kan herbeleef (Clinton, Hart \& Ohlschlager 2005:89). Die beradene se emosies en die intensiteit daarvan is gewoonlik direk aan die herinneringe van die verlede gekoppel (Wright 1985:48; Stoop \& Masteller 2004:102). Daarom kan die berader begin deur die beradene uit te vra na dit wat aanleiding gegee het tot die stap om om hulp te kom aanklop. Soos wat die beradene sy of haar storie vertel, moet die berader ingestel wees om na hom of haar én na die Heilige Gees te luister (Tan 2007:2). Indien die beradene nie die simptome aan 'n spesifieke oorsaak kan koppel nie, moet die berader bid dat die Here moontlik belangrike aspekte uit die verlede in sy of

1.In die navorsing is verskillende gebedsintervensie-modelle ondersoek en vervolgens word hier op eklektiese wyse stappe weergegee wat voorgehou kan word as 'n model vir gebedsterapie in die herwinning en verwerking van traumageheue. 
haar geheue na vore sal bring (vgl. Jer 33:3; Joh 14:21). Dit is soms nodig om op 'n baie kinderlike manier te bid, omdat emosionele verwonding moontlik op 'n baie jong ouderdom plaasgevind het en die beradene hom- of haarself juis aan daardie diepgevestigde herinneringe moet oorgee. ${ }^{2}$ Indien die beradene die simptome aan 'n spesifieke oorsaak kan koppel, kan daar voortgegaan word met die proses (Thiessen 2009:82).

Dit is sinvol om as deel van die voorbereidingsproses ook iets van die werking van die brein ${ }^{3}$ met betrekking tot traumatiese geheue aan die beradene te verduidelik en basiese agtergrond soos die volgende is belangrik in hierdie verband (Schiraldi 2000:15; Capacchione 1991:37): Emosionele traumatiese geheuemateriaal word normaalweg nie ordelik gestoor of verbind nie, omdat dit in die amigdalagedeelte van die brein gestoor word. Hierdie herinneringe word gewoonlik afgekamp en gevolglik nie geliasseer in die langtermyngeheue nie (McMinn 1997:18). Die pynlike herinneringe word ook nie in narratiewe vorm gestoor nie, maar in die vorm van sensuele indrukke. Dit word wel in baie duidelike detail gestoor, maar in losstaande eenhede sonder die nodige verbintenisse met mekaar. Matsakis (1998:195) wys daarop dat hierdie herinneringe gewoonlik baie na aan die oppervlak lê en baie maklik geaktiveer of gesneller kan word deur enige herinnering aan die trauma of selfs dinge wat met die sneller geassosieer kan word. Navorsing het ook aangetoon dat hierdie pynlike herinneringe in die amigdala oor die algemeen slegs deur die abstrakte bereik kan word, soos byvoorbeeld deur spelterapie, dans, ritme, spel sonder woorde, visualisering, gebed en simboliek (Van der Kolk \& Fisler 1995). Traumatiese geheue laat 'n mens dikwels soos 'n ander persoon voel. Dit is asof daar tydens die trauma iets met sy of haar persoonlikheid gebeur het en hierdie andersheid word ervaar sodra die herinneringe gesneller word. Dit is 'n toestand waar die persoon oor die algemeen talle verkeerde kognitiewe stellings glo en as die waarheid aanvaar. Regdeur die terapeutiese proses gaan die fokus gevolglik daarop gerig wees om hierdie leuens te herken en te korrigeer (Herman 1997:37). Soms sal die leuen, wat geglo word as gevolg van die traumatiese gebeurtenis, vir die berader voor die hand liggend wees, terwyl die beradene self nog nie die insig daarin het nie (Bryant, Kessler \& Shirar 1992:155). In sulke gevalle sal die berader hom- of haarself voortdurend daaraan moet herinner dat gebedsterapie 'n God-gerigte proses is en dat die berader slegs die fasiliteerder is en die beradene self tot die nodige insig moet kom (Seamands 2001:129).

\section{Stap 2 (Fase 1): Identifiseer die skakels tussen die huidige probleemarea en die herinneringe}

Volgens Smith (1999:104) weet die beradene gewoonlik wat die probleem is wanneer hy of sy aanmeld vir terapie.

2.'n Stelling soos hierdie kan moontlik die kritiek ontlok dat die pastorale berader op 'n onetiese wyse omgaan met die emosies van die beradene. Vir innerlike genesing om te kan plaasvind, is dit egter belangrik dat alle emosies erken moet word en soms sal die beradene die emosies as ' $t$ ware weer herbeleef. Die pastorale berader moet die beradene met groot sorg en ondersteuning deur hierdie proses begelei. Sien ook 'Stap 1 (Fase 2): Berei die weg vir genesing deur middel van gebed', vir 'n duideliker omskrywing.

3.Die werking van die brein met betrekking tot traumatiese gebeure is ' $n$ hoogs gespesialiseerde veld en die outeur wil geensins hierdie gebeure vereenvoudig nie. gespesialiseerde veld en die outeur wil geensins hierdie gebeure vereenvoudig nie.
Hierdie verduideliking is slegs ' $n$ baie basiese verduideliking om iets van die proses Hierdie verduideliking is slegs ' $n$ baie
aan die beradene te kan verduidelik.
Hy waarsku egter dat hierdie (huidige) probleem in die meeste gevalle nie die ware pyn is nie, maar slegs ' $n$ eggo van die oorspronklike pyn ten opsigte van die onderdrukte en onverwerkte emosionele bagasie. Wanneer die berader dus dieper luister en die nie-verbale kommunikasie van die beradene waarneem, sal hy of sy baie gou bewus word van die skadufigure vanuit die verlede (Wright 1985:53; Stoop \& Masteller 2004:102). Die Heilige Gees sal die berader bewus maak, soms deur net blote indrukke of vermoedens, van belangrike leidrade. Die berader moet sensitief wees vir enige gebeure in die beradene se verlede wat skakels met die huidige probleme kan hê, asook vir verkeerde gesindhede teenoor die self, ander en God. Hierdie bewuswording is nie ' $n$ poging om iemand te soek om te blameer vir die pyn nie, maar om insig in die herinnering te kan verkry (Wright 1985:52). Hemfelt, Minirith en Meier (1989:180) vergelyk hierdie proses met ' $n$ rit in 'n tuimeltrein (roller coaster) en verduidelik dat dit vir die beradene sal voel asof dit eers slegter gaan voordat daar genesing intree.

Wanneer iemand aanmeld vir terapie is dit asof hulle verwag dat dit dadelik beter moet gaan. Dit is egter ' $n$ pynlike proses om die wortels van die seer en pyn te identifiseer. Daarom moet die berader die beradene sensitief begelei en verseker van Jesus Christus se aanhoudende teenwoordigheid (Thiessen 2009:82). Soms gaan hierdie pyn ook baie ver terug in die verlede en moet daar heel dikwels in die kinderjare gedelf gaan word. Vyf en tagtig persent van die volwassene se persoonlikheid word gevorm voor die ouderdom van ses jaar en dikwels het baie van die emosionele skade reeds hier plaasgevind (Meier \& Wise 2003:142). Die oorspronklike pynlike herinneringe verkry in hierdie proses gaandeweg al meer gestalte deur sekere beskrywende emosionele woorde of uitdrukkings, gesindhede en selfs fisiese manifestasies wat uiteindelik alles op een of ander wyse bydra tot die huidige probleem (Colbert 2003:7). Dit gebeur dikwels dat die huidige emosies slegs sekondêre emosies is. Sekondêre emosies is dié wat in enige gegewe situasie teenwoordig is, maar waarvan die wortel in diep, onderdrukte en onverwerkte emosionele en pynlike herinneringe gesetel is. Die emosies wat die beradene beleef, is geregverdigde en toepaslike emosies tydens van die herinnering, maar die voortdurende manifestasie van die emosies in die persoon se huidige omstandighede is destruktief en vernietigend op die lang duur (Anderson et al. 2000:286; Capacchione 1991:24; Langberg 2003:120). Tydens hierdie herkennings- en erkenningsproses sal die beradene deur 'n sekere rouproses gaan, veral met betrekking tot groot verliese in die verlede. Die emosies wat ten opsigte van die rouproses ervaar word, is baie nou gekoppel aan die aard van die emosionele verwonding wat plaasgevind het. Sodoende sal 'n beradene wat as kind gemolesteer is, byvoorbeeld rou oor die verlies van haar maagdelikheid en die impak wat dit op haar latere seksuele lewe gehad het. Alhoewel sy genesing ten opsigte van die molestering kan ontvang, is daar sekere aspekte wat sy nooit terug kan kry nie en wat as 't ware van haar gesteel is. Dit is belangrik dat sulke gevoelens van verlies nie ontken word nie, maar ook deurgewerk word. Die beradene moet rou oor dit wat hy of sy as 't ware verloor het of wat gesterf het as gevolg van die oorspronklike gebeurtenis of oor dinge 
wat hom of haar toegekom het, maar wat hy of sy nooit ontvang het nie (Bryant et al. 1992:155).

Soms kan die beradene nie vanselfsprekend die konneksie maak tussen huidige probleme, verhoudingspanning, kompulsies, verslawings en ander simptome enersyds en onverwerkte, onderdrukte emosionele bagasie andersyds nie (Smith 1999:107; Trollinger 2007:53). Die tipiese tendens is dan om op die huidige probleme te fokus. Innerlike genesing en vryheid is egter nie gesetel in die verandering van die huidige omstandighede nie, maar grotendeels in die erkenning en verwerking van die oorspronklike pyn. Onderdrukte, onverwerkte emosionele pyn intensiveer net verder die huidige, reeds intense situasie. Die huidige probleme veroorsaak ook pyn en ongemak en dit kan nie geminimaliseer of geïgnoreer word nie, maar totdat die wortel geïdentifiseer en verwerk word, sal die beradene slegs tydelike verligting in die huidige situasie ontvang (Colbert 2003:24).

Nadat al die nodige inligting tydens die onderhoudvoering ingewin is, moet die berader ingestel wees op die leiding van die Heilige Gees betreffende die rigting wat die beradingsessie moet neem. Die berader kan byvoorbeeld gelei voel om dadelik oor te gaan tot gebed, of om eers die beradene te lei na belydenis, die uitspreek van vergifnis, ensovoorts.

\section{Stap 3 (Fase 1): Identifiseer die oorspronklike leuen wat gevestig is}

Hierdie stap is somtyds die moeilikste, maar ook die mees kritiese. Totdat die werklike oorspronklike leuen en verkeerde denkpatrone geïdentifiseer word, kan genesing nie volkome intree nie (Botha 2009:137). Hierdie stap is veral belangrik tydens die beradingsproses wanneer die beradene onwaarhede aangaande hom- of haarself in die lig van die Bybel glo en wanneer irrasionele denkpatrone hom of haar verhoed om 'n vry en produktiewe lewe te lei, soos wat God vir die mens bedoel het (Anderson \& Miller 2000:223). Die beradene se Godsbeskouing is slegs 'n projeksie van die beskouing van sy of haar aardse vader of moeder (Meier \& Meier 2002:51). In hierdie opsig sal 'n negatiewe Godsbeskouing enige geestelike groei blokkeer en daarom is dit so belangrik dat die leuen geïdentifiseer sal word. Vir die identifisering en die uiteindelike vervanging van die leuen met die waarheid, is dit gevolglik belangrik dat die beradene se denkpatrone sal verander (Backus \& Chapian 1980:15).

Die beradene sal in voeling kan kom met sy of haar volwasse gevoelens wanneer sy of haar kinderlikeemosies geïdentifiseer en verwerk kan word (Whitfield 1989:77; Dickinson \& Page 1989:130). Die beradene se herinneringe is nie noodwendig 'n akkurate weergawe van die werklike gebeure nie, want elkeen vertolk 'n spesifieke gebeurtenis na aanleiding van sy of haar eie persepsies, voorveronderstellings en emosionele volwassenheid ten tye van die gebeurtenis (Thurman 1999:6). Tydens die beradingsproses gaan dit egter nie daaroor om die gebeure as waar of onwaar te bewys nie, maar om die beradene se persoonlike oortuiging as gevolg van die gebeurtenis te identifiseer (Clinton et al. 2005:428; Thiessen 2009:82). Leuens oor die self, ander, die wêreld en God moet gevolglik geïdentifiseer word, sodat dit verwerk kan word (Botha 2009:137).

Die beradene moet in hierdie proses let op sy of haar verbeeldingsvlugte, liggaamlike, emosionele en gedragsensasies (Fredrickson 1992:101). Die beradene se gedrag is ' $n$ belangrike leidraad in die proses van herkenning. Wanneer die beradene as kind 'n gebrek aan onvoorwaardelike aanvaarding beleef het, sal hy of sy 'n kompulsiewe drang hê om sy of haar ouers te plesier (Arterburn, Meier \& Wise 2002:57). Wanneer hy of sy nie daarin slaag nie, mag hy of sy hom- of haarself as 'n mislukking beleef en dan rebelleer teen alle verdere gesag. In hierdie opsig moet die berader dus met fyn onderskeidingsvermoë luister en die Heilige Gees vertrou vir die bewuswording van die koppeling tussen die huidige gedrag van die beradene en die oorspronklike leuen. Emosionele eggo's is belangrike leidrade vir die identifisering van die leuen, want die mens 'voel wat hy of sy glo' (Smith 1999:110, 2007:51). Die leuen is diep gevestig in die donker herinneringe en alhoewel die beradene dit dikwels op logiese vlak as 'n leuen kan erken, voel dit op emosionele vlak soos die absolute werklikheid. 'n Voorbeeld hiervan is wanneer die beradene sê: 'Ek weet ek behoort nie so te voel nie, maar ek kan nie anders nie.' Die berader moet die beradene begelei om te fokus op wat waar vóél en nie op wat hy of sy weet (logika) waar is nie. Die oorspronklike leuen sal waar voel vir die beradene, selfs al wéét hy of sy dit is nie waar nie.

'n Nuttige hulpmiddel is om die beradene te vra om te beskryf wat hy of sy voel en dít dan met verdere beskrywende woorde te definieer (Smith 1999:111). Soms kruip die leuen net onder die vlak van logika en verdedigingsmeganismes weg. Vrae soos wat, hoekom en waarom help die beradene gevolglik om dieper en dieper in die herinnering in te beweeg totdat die leuen ten volle geïdentifiseer is. ' $n$ Verdere manier om die leuen te identifiseer, is gesetel in die observering van die beradene se huidige gedrag en probleem (Smith 1999:103). Die leuen manifesteer dikwels in die beradene se funksioneringstyl en gesindheid teenoor die lewe. Die berader kan byvoorbeeld begin deur die beradene uit te vra na die emosie wat hy of sy as die waarheid omtrent homself glo. Vervolgens word daar na herinneringe in die verlede gesoek wat aan hierdie emosie gekoppel kan word. Om die huidige situasie slegs kognitief te analiseer, mag lei tot groter verstaanbaarheid en insig, maar dit kan nie tot uiteindelike bevryding van die houvas wat die leuen op die beradene se lewe het, lei nie (Jantz \& McMurray 2003:207). Op hierdie stadium moet daar dan spontaan oorgegaan word tot die gespreksgebed, wanneer die berader die beradene onder gebed na Jesus Christus begelei, sodat genesing deur Christus kan intree.

\section{Fase 2: Die gespreksgebed}

Ohlschlager en Scalise (2007:19) se fokus tydens hierdie fase is op die begeleiding ten opsigte van die identifisering 
van moontlike oplossings. Dit hou veral verband met insig, duidelikheid, probleemoplossing, doelwitstelling, die daarstel van 'n toekomsvisie, resultate en uitkomste. Die beradene word gehelp om doelstellings te formuleer om op 'n skeppende wyse antwoorde op sy of haar diepste behoeftes en begeertes te verkry. Draper (1996:149-206) stel dit dat die grootste fokus in hierdie fase op die innerlike van die beradene is, waartydens verandering en bekering die twee grootste moontlike uitkomste is. Vir Langberg (2003:215) is die vestiging van 'n sterk terapeutiese alliansie belangrik, sodat die traumageheue herwin en verwerk kan word. Die fase bestaan uit drie stappe wat interaktief is.

\section{Stap 1 (Fase 2): Berei die weg vir genesing deur middel van gebed}

Kraan (1983:136) beskryf hierdie tipe gebed vir innerlike genesing as geïntensiveerde gebed en beklemtoon die krag van hierdie tipe gebed na aanleiding van Jakobus 5:16. Die berader moet gevolglik die geloof en vrymoedigheid hê om God te vertrou vir genesing en vernuwing wanneer hy of sy die beradene in gebed na Hom bring. Tydens hierdie proses bring die Heilige Gees die onaangename herinneringe vir die beradene na die oppervlakte (bewussyn) vir genesing (Seamands 1993:20). Genesing tree nie vanselfsprekend in wanneer die oorspronklike gebeure skielik onthou kan word nie, maar wanneer die beradene die Waarheid in hierdie gebeurtenis kan ontvang en beleef, dit lei gewoonlik tot ' $n$ totale nuwe perspektief op die betrokke gebeure (Clinton et al. 2005:428). Wanneer die oorspronklike gebeure dan op hierdie wyse herbeleef word, tesame met die besef dat Jesus Christus eintlik tydens die gebeurtenis teenwoordig was en die beradene beskerm het, het dit die gevolg dat emosionele genesing intree en dat die pynlike emosionele wond getransformeer word tot 'n pynlose letsel (Kraft 1993:117; Tan 2007:3; Thiessen 2009:82). Op die webblad van MacNutt (2005) som hy dit treffend op wanneer hy sê: 'God doesn't reveal something unless He intends to heal it.' Die berader begin die gebed deur die beradene te begelei om hom- of haarself te visualiseer in gesprek met Jesus Christus oor al die pynlike herinneringe van die verlede. Die beradene moet dit doen vir solank as wat dit vir hom of haar nodig is, want dit is uiteindelik hierdie teenwoordigheid van Jesus Christus wat heling en genesing bewerkstellig (Hicks 1996:158).

Alhoewel hierdie stap die kern van gebedsterapie is, is dit seker ook die mees radikale stap. Die kritiek is trouens al gelewer dat dit die getraumatiseerde persoon weer 'n tweede keer aan dieselfde trauma sou blootstel (Botha 2009:139; Matsakis 1998:261). Smith (1999:116) verduidelik egter die noodsaaklikheid van die herbelewing van die traumatiese herhinnering in die sin dat dit die interpretasie van die gebeurtenis is wat die pyn laat vestig het en nie die gebeurtenis self nie. Wanneer die herinnering herbeleef word, vind daar eerstens emosionele ontlading plaas en tweedens word 'n geleentheid geskep waar Jesus Christus genesing in die herinneringe kan bring. Die emosionele pyn beïnvloed die persoon se funksioneringstyl elke dag van sy of haar lewe, hetsy bewustelik of onbewustelik (Seamands
1982:196; Matsakis 1998:266). Besluiteloosheid, gevoelens van twyfel en wanhoop, die behoefte om te alle tye in beheer te wees, vrese, selfhaat en gebroke verhoudings blyk maar net die refleksie van pynlike herinneringe en 'n toonbeeld van die mag wat hierdie pyn oor die beradene se lewe uitoefen, te wees. Die ontkenning en onderdrukking van emosionele pyn in 'n poging om daarvan te ontsnap, sal gevolglik lei tot die versterking van die houvas daarvan op die beradene se lewe (Whitfield 1989:78). Tydens die herbelewing van die herinneringe word die beradene nou begelei om te fokus op die geheueprentjie en sal hy of sy die emosies intens beleef soos tydens die werklike gebeurtenis (Smith 1999:121). Hierdie herbelewing bevestig die leuen wat geglo word as gevolg van die traumatiese gebeurtenis, byvoorbeeld: Ek is vasgevang en daar is geen manier hoe ek kan ontsnap nie. Wanneer hierdie intensiteit beleef word, moet die berader vervolgens bid dat God die waarheid aan die beradene sal uitwys, die leuen sal uitkanselleer en sodoende genesing bewerkstellig (Seamands 1993:20; MacNutt 1999:147).

Wanneer die Heilige Gees nie 'n spesifieke herinnering na die beradene se bewussyn bring nie, moet daar in gebed stelselmatig deur al die inligting gewerk word wat tydens die terapeutiese gesprek aan die lig gekom het (Kraft 1993:100). Daar moet gebid word dat Jesus Christus alle tersaaklike herinneringe na die bewussyn sal bring en die beradene moet dan gevra word om Jesus Christus op een of ander wyse in die herinneringe te beleef (MacNutt 1999:147; Richardson 2005:34). Gebedsterapie berus nie op begeleidende voorstellings of suggesties nie en daarom moet die berader die beradene slegs maar bewus maak van Jesus Christus se alomteenwoordigheid. Soms gebeur dit dat die beradene vir Jesus Christus in die geheueprentjie sal sien of Hom sal hoor, en ander kere sal dit slegs 'n intense bewustheid van sy teenwoordigheid wees waartydens die beradene die sekere wete en gevoel sal ervaar dat alles nou in orde is (Thiessen 2009:82; Kuchan 2009). Tydens daardie ervarings waar die beradene dan wel genesing ervaar, sal sy of haar hele houding die verligting uitstraal.

'n Gebedsessie soos hierdie is gewoonlik 'n emosioneel uitputtende ervaring (Seamands 2001:161). Die beradene kan dit beleef asof iets van hom of haar weggeneem is en onttrekkingsimptome kan selfs in sommige gevalle ontstaan. Daar kan selfs werklike fisiese simptome beleef word, soos byvoorbeeld erge hoofpyn, naarheid, braking, diarree of intense uitputting. Hierdie simptome kom nie in alle gevalle voor nie, maar dit is goed om daarop voorbereid te wees.

In kontras met die meeste ander navorsers se riglyne vir die gespreksgebed beklemtoon Adams (1979:76) dat dit 'n wilsaksie is en dat daar nie op die emosie gefokus moet word nie, omdat die emosies subjektief is. Hy sê in hierdie verband dat die eerste stap gebed is, die tweede stap die vernuwing van die denke van die beradene, en die derde stap die oorgaan tot die toepaslike aksies. Eers daarna sal vrede volg. Adams se standpunt is egter debatteerbaar in die sin dat dit wil voorkom asof hy die emosionele dimensie ondergeskik aan 
die kognitiewe- en wilsdimensie plaas. Die hele essensie van gebedsterapie is juis daarop gerig dat die emosionele erken en verwerk moet word, sodat genesing kan intree. Kognitiewe instemming alleenlik lei nie tot emosionele genesing nie. Die vraag kan gevra word of Adams se voorgestelde model nie bloot aangeleerde gedragspatrone tot gevolg het nie, terwyl die emosionele pyn en wonde verder onderdruk en ontken word. Dit is dan juis hierdie onderdrukte, onverwerkte emosionele wonde wat die beradene se emosionele en geestelike groei kortwiek.

\section{Stap 2 (Fase 2): Verwyder versperrings wat genesing voorkom}

Wanneer daar tot by hierdie stap gevorder is en die beradene dit steeds moeilik vind om die waarheid van God met betrekking tot sy of haar spesifieke situasie ten volle te aanvaar, is daar gewoonlik iewers 'n versperring wat moontlike genesing verhoed (Minnirth \& Meier 1990:35-46; Smith 1999:125). Hierdie versperring moet eers uit die weg geruim word voordat daar verder met die gebed gegaan kan word (Kraft 1993:23). Versperrings is onder andere 'n vermyding van die herbeleef van die pyn; so 'n groot begeerte by die beradene om deur die berader aanvaar te word dat hy of sy 'n front voorhou; oormatige logiese beredeneringe; onbelyde sondes; onvermoë om die leuen te identifiseer; demoniese invloede; emosionele dissosiasie; of die teenwoordigheid van woede, haat en wraakgevoelens.

\section{Stap 3 (Fase 2): Sluit die gebed af}

Die berader kan ter afsluiting van die gebed toepaslike Skrifgedeeltes lees, terwyl die beradene begeer om Jesus Christus se teenwoordigheid steeds intens te beleef (Smith 1999:132; Rayborn 2005:74). Innerlike genesing is uiteindelik ook meer as die blote genesing van pynlike herinneringe of die genesing van die sogenaamde innerlike kind. Dit het eerder te make met volkome heelwording, hetsy geestelik, psigies, fisies of sosiaal. Deur die gemeenskap met Jesus Christus kan hierdie persoon nou die doel van sy of haar lewe ontdek en sy of haar volle potensiaal bereik (Hicks 1996:163).

\section{Fase 3: Nasorg en begeleiding tot emosionele en geestelike groei}

Nadat emosionele genesing ingetree het, is dit belangrik dat heelwat van die beradene se alledaagse gewoontes en gedrag ook sal verander en hiervoor is voortdurende gebedsondersteuning en aanspreeklikheid tot en deur medegelowiges noodsaaklik (Kraft 1993:101). Die fokus verskuif na uiterlike genesing, waar 'n aspek soos onder andere verhoudingsvaardighede onder die loep geneem word (Draper 1996:149-206). Die daarstel van grense op persoonlike en sosiale vlak is vervolgens ook baie belangrik, terwyl die beradene stelselmatig gelei word om weer beheer oor, en verantwoordelikheid vir sy of haar eie lewe te neem en hom- of haarself te begin handhaaf.

\section{Slot}

Die fokus in hierdie artikel het geval op die pastorale berader wat die Christenpersoon vanuit ' $n$ Christelike basis begelei tot geestelike en emosionele genesing. Die vraagstuk wat ondersoek is, is of gebed enigsins deel kan uitmaak van die proses van die herwinning en verwerking van traumageheue in die innerlike genesingsproses. Alhoewel gebed dikwels in die verlede met agterdog bejeën is, kan die afleiding gemaak word dat gebed tydens die pastorale begeleiding ' $n$ belangrike deel uitmaak van die herwinning en verwerking van onderdrukte, onverwerkte emosies rakende traumagebeure in die lewe van die beradene.

Navorsing het getoon dat herinneringe aan die onderdrukte, onverwerkte traumageheue maklik deur verskillende aspekte gesneller word en daarom gaan die slagoffer van sulke gebeure soms lewenslank gebuk onder die gevolge van hierdie onderdrukte, onverwerkte emosionele wonde. Aangesien hierdie herinneringe slegs deur die abstrakte bereik kan word, is gebedsterapie 'n belangrike hulpmiddel in hierdie proses. Dit word egter beklemtoon dat hierdie vorm van terapie nie begeleidende voorstellings of suggesties is nie, en niks meer of minder is as 'n gebed waarin God self die beradene op die vlak van die innerlike met genesing bedien nie.

\section{Erkenning Mededingende belange}

Die outeurs verklaar dat hulle geen finansiële of persoonlike verbintenis het met enige party wat hulle nadelig kon beïnvloed in die skryf van hierdie artikel nie.

\section{Outeurs bydrae}

B.J.d.K. (Noordwes-Universiteit) was die projekleier, A.L.d.P. (Noordwes-Universiteit) het die manuskrip voorberei en geskryf.

\section{Literatuurverwysings}

Adams, J.E., 1979, A Theology of Christian Counseling, Zondervan, Grand Rapids, MI. Allender, D.B., 1995, The wounded heart, Nav Press, Colorado Springs.

Anderson, N.T. \& Miller, R., 2000, Bevryding van vrees, Christelike Uitgewersmaatskappy (CUM), Vereeniging.

Anderson, N.T., Zeulke, T.E. \& Zeulke, J.S., 2000, Christ centered therapy, Zondervan, Grand Rapids, MI.

Arterburn, S., Meier, P.D. \& Wise, R.L., 2002, Fear less for life, Break free to living with hope and confidence, Thomas Nelson, Nashville, TN.

Backus, W. \& Chapian, M., 1980, Telling yourself the truth, Bethany House, Minneapolis, MN.

Berkhof, H., 1973, Christelijk geloof. Een inleiding tot die geloofsleer, p. 513, Nijkerk: Uitgeverij G.F., Callebach.

Botha, J.U., 2009, 'Theophostic Prayer Ministry (TPM): 'n Prakties teologiese beoordeling', PhD-proefskrif, Noordwes-Universiteit, Potchefstroom.

Bounds, E.M., 1984, Praying that receives answers, p. 39, Whitaker House, New Kensington.

Bryant, D., Kessler, J. \& Shirar, L., 1992, The family inside, Working with the multiple, W.W. Norton, New York, NY.

Campbell-Lane, Y., 2003, 'Inner change: A pastoral-theological study', PhD-proefskrif, Noordwes-Universiteit, Potchefstroom.

Campbell-Lane, Y. \& Lotter, G.A., 2005, 'Biblical counseling regarding inner change', Koers 70(1), 99-123.

Capacchione, L., 1991, Recovery of your inner child, The highly acclaimed method for liberating your inner self, Simon and Schuster, New York, NY.

Clinton, T., Hart, A. \& Ohlschlager, G., 2005, Caring for people God's Way, Thomas Nelson, Nashville, TN.

Cloud, H. \& Townsend, J., 2002, God will make a way, What to do when you don't know what to do, Integrity, Nashville, TN. 
Dickinson, R.W. \& Page, C.G., 1989, The child within each of us, Healing wounds of childhood that hinder our growth as adults, SP Publications, USA

Draper, P.L., 1996, Haunted memories, Healing the pain of childhood abuse, Fleming H. Revell, Grand Rapids, MI.

Du Plessis, A.L., 2007, 'Die rol van gebed by die proses van innerlike genesing: 'n Pastorale studie', PhD-proefskrif, Noordwes-Universiteit, Potchefstroom.

Ferguson, J.K., Willemsen, W. \& Castarieto, M.V., 2010, 'Centering prayer as a healing response to everyday stress: A psychological and spiritual process', Pastora Psychology 59(3), 305-329.

Fredrickson, R., 1992, Repressed memories, A journey to recovery from sexual abuse, Rockefeller Centre, New York, NY.

Friesen, J.G., 1997, Uncovering the mystery of MPD, Wipf and Stock, OR.

Goldsworthy, G., 2003, Prayer and the knowledge of God, p. 183, Inter Varsity Press, Leicester, UK.

Gubi, P.M., 2001, 'An exploration of the use of Christian prayer in mainstream counseling', British Journal of Guidance and Counselling 29(4), 425-433.

Gushee, D.P., 2007, 'Jesus and the sinner's prayer: What Jesus says doesn't match what we usually say', Christianity Today 51(3), 72.

Hemfelt, R., Minirith, F. \& Meier, P.D., 1989, Love is a choice, The groundbreaking book on recovery for codependent relationships, Thomas Nelson, Nashville, TN.

Herman, J.L., 1997, Trauma and recovery from domestic abuse to political trauma Pandora, Londen.

Hicks, R., 1996, Trauma, The pain that stays, Fleming H. Revell, Grand Rapids, MI.

Jantz, G.L. \& McMurray, A., 2003, Healing the scars of emotional abuse, Fleming H. Revell, Grand Rapids, MI.

Jones, I.F., 2007, 'Inner healing and therapeutic prayer: The parameters and power of prayer in counseling', Christian counseling today (15)2, 25-27.

Kraan, K.J., 1983, Genezing en bevrijding, Uitgeversmaatschappij J. H. Kok, Kampen.

Kraft, C.H., 1993, Deep wounds, deep healing, Discovering the vital link between spiritual warfare and inner healing, Regal Books, CA.

Kuchan, K.L., 2009, 'Prayer as a therapeutic process toward transforming destructiveness within a spiritual direction relationship', Journal of religion and health 10(1007), besigtig op 04 Februarie 2011, by http://www.springerlink.com/ context/t51m631/3xg60975/

Langberg, D.M., 2003, Counselling survivors of sexual abuse, Xulon Press, USA.

Lindeque, R.C., 2006, 'Die pastorale berading van persone met gekompliseerde trauma', PhD-proefskrif, Noordwes-Universiteit, Potchefstroom.

MacNutt, F., 1999, Healing, Ave Maria Press, Notre Dame.

MacNutt, F., 2005, The healing line: Praise the Lord and give thanks, besigtig op 07 November 2007, by http://www.christianhealingmin.org/newsletter/archives/ testimonies/praisethelord.php

Matsakis, A., 1998, Trust after trauma: A guide to relationships for survivors and those who love them, New Harbinger, Oakland, CA.

McMinn, M.R., 1996, Psychology, theology and spirituality in Christian counseling, Tyndale House, IL.

McMinn, M.R., 1997, 'Dissociative identity disorder: What is DID?', Christian Counselling Today 5(1), 17-21.

Meier, C. \& Meier, P.D., 2002, Unbreakable bonds, Practicing the art of loving and being loved, Baker Books, Grand Rapids, MI.
Meier, P.D., Arterburn, S. \& Minirth, F.B., 1999, Mood swings: Understand your emotional highs and lows and achieve a more balanced and fulfilled life, Thomas Nelson, Nashville, TN.

Meier, P.D. \& Wise, R.L., 2003, Crazy makers, Thomas Nelson Publishers, Nashville, TN.

Minirth, F.B., 2003, The Minirth guide for Christian Counselors, Broadman \& Holman, Nashville, TN.

Minirth, F.B., Hawkins, D., Meier, P. \& Flournoy, R., 1986, How to beat burnout, Moody Press, Chicago.

Minirth, F.B. \& Meier, P.D., 1990, Counseling and the nature of man, Baker Book House, Grand Rapids, MI.

Ohlschlager, G. \& Scalise, E., 2007, 'The five stages of competent Christian counseling: Toward a "common factors/best practices" process', Christian counseling today 15(2), 19-24.

Poloma, M.M., 2009, 'Pentecostal prayer within the Assemblies of God: An empirical study', Pneuma 31(2009), 47-65.

Rayborn, P., 2005, 'When mountains don't move', Christianity Today 49(12), 74.

Richardson, R., 2005, Experiencing healing prayer, InterVarsity Press, IL.

Sandford, J. \& Sandford, P., 1982, The transformation of the inner man, Victory House, Tulsa, OK.

Schiraldi, G.R., 2000, The post-traumatic stress disorder sourcebook, A guide to healing, recovery and growth, Lowell House, IL.

Seamands, D.A., 1982, Putting away childish things, SP Publications, IL.

Seamands, D.A., 1993, Healing your heart of painful emotions, Edison Inspirational Press, New York, NY.

Seamands, D.A., 2001, Healing of memories, SP Publications, IL.

Seamands, D.A. \& Funk, B., 1992, Healing of damaged emotions: Recovering from the memories that cause our pain, Cook Communications, Colorado Springs.

Sinclair, N.D., 1993, Horrific traumata: A pastoral response to the post-traumatic stress disorder, Haworth Pastoral Press, New York, NY.

Smith, E.M., 1999, Beyond tolerable recovery, Alathia Publishing, USA.

Smith, E.M., 2007, 'Theophostic prayer ministry: adjunctive use in Christian counseling', Christian counseling today 15(2), 50-52.

Stein, R.H., 1992, The new American commentary: Luke, Broadman Press, Nashville, TN.

Stoop, D. \& Masteller, J., 2004, Forgiving our parents, forgiving ourselves: Healing adult children of dysfunctional families, Servant Publications, Ann Arbor, MI.

Tan, S., 2007, 'Inner healing prayer', Christian counseling news from the ACC in SA office $2-4$, First semester.

Thiessen, W.J., 2009, 'Praying in a new reality: A social constructionist perspective on inner healing prayer', PhD-proefskrif, UNISA, Pretoria.

Thurman, C., 1999, The lies we believe in, Thomas Nelson Publishers, Nashville, TN.

Trollinger, S., 2007, Advanced triage counseling, Higher Life Press, Florida.

Whitfield, C.L., 1989, Healing the child within: Discovery and recovery for adult children of dysfunctional families, Health Communications, FL.

Wright, H.N., 1985, Making peace with your past, Fleming H. Revell, Grand Rapids, MI.

Van der Kolk, B.A. \& Fisler, R., 1995, 'Dissociation and fragmentary nature of traumatic memories: overview and exploraty study', besigtig op 12 Mei 2007, by http:// www.trauma-pages.com

Zerfass, R., 1974, Praktische Theologie Heute, Kaiser/Grünewald, München. 